Jurnal Media Komunikasi Pendidikan Pancasila dan Kewarganegaraan

Volume 2, Nomor 1 April 2020

\title{
PENEGAKAN PELANGGARAN KEDAULATAN OLEH PESAWAT SIPIL ASING DI WILAYAH YURISDIKSI NASIONAL
}

\author{
Desi Yunitasari \\ Jurusan Hukum dan Kewarganegaraan \\ Fakultas Hukum dan Ilmu Sosial Universitas Pendidikan Ganesha Bali \\ E-mail: yunitasaridesi693@gmail.com
}

\begin{abstract}
Abstrak
Pengakuan dunia terhadap wilayah udara sebagai bagian dari kedaulatan negara memberikan legitimasi yang kuat bagi Indonesia sebagai suatu negara yang luas. Namun kondisi ini dapat berubah manakala Indonesia tidak mampu menguasai wilayah kedirgantaraannya sebagai penopang ekonomi dan pertahanan nasional. Ditambah dengan masalah pelanggaran batas kedaulatan yang sering dilakukan oleh pesawat militer negara asing. Penelitian ini dilakukan dengan mengidentifikasi tiga permasalahan, yaitu (1) bagaimana konsep kedaulatan negara di ruang udara menurut hukum internasional dan peraturan perundangan nasional, (2) apa saja bentuk pelanggaran kedaulatan negara di ruang udara nasional, dan (3) bagaimana upaya penegakan atas pelanggaran kedaulatan negara di ruang udara nasional dalam menjaga pertahanan negara. hasil penelitian menyimpulkan bahwa (1) baik hukum internasional dan peraturan perundangan nasional telah mengukuhkan kedaulatan negara di ruang udara yang bersifat penuh dan utuh (complete and exclusive), (2) sejumlah insiden pelanggaran izin masuk dan melintasnya pesawat-pesawat asing ke wilayah udara Indonesia, di mana kebanyakan dari pesawat asing tersebut adalah pesawat militer, dan (3) upaya penegakan atas pelanggaran kedaulatan di wilayah ruang udara nasional, antara lain penegakan hukum terhadap pelanggaran wilayah udara kedaulatan NKRI. Sehingga kedaulatan adalah otoritas tertinggi yang dimiliki oleh negara. Dalam kedaulatan diputuskan berisi hal-hal yang berkaitan dengan kekuasaan dan tanggung jawab untuk wilayah negara.
\end{abstract}

Kata Kunci: prinsip tanggung jawab, pesawat asing, negara pengirim, negara penuntut, wilayah yurisdiksi

\begin{abstract}
World recognition of airspace as part of state sovereignty provides strong legitimacy for Indonesia as a vast country. However, this condition can change if Indonesia is unable to control its aerospace territory as a support for the economy and national defense. Add to this the problem of sovereignty violations that are often carried out by foreign military aircraft. This research was conducted by identifying three problems, namely (1) how the concept of state sovereignty in air space according to international law and national legislation, (2) what forms of violations of state sovereignty in national air space, and (3) how to enforce violations state sovereignty in national air space in maintaining national defense. the results of the study concluded that (1) both international law and national laws and regulations have confirmed the sovereignty of the state in air space that is full and complete (complete and exclusive), (2) a number of incidents of violations of
\end{abstract}


entry permits and passage of foreign aircraft into Indonesian airspace, where most of the foreign aircraft are military aircraft, and (3) enforcement efforts for violations of sovereignty in national airspace, including law enforcement against violations of the Republic of Indonesia's sovereign airspace. So that sovereignty is the highest authority owned by the state. In sovereignty it is decided to contain matters relating to power and responsibility for the territory of the country.

Keywords: principle of responsibility, foreign aircraft, sending country, jurisdiction

\section{Pendahuluan \\ Latar Belakang}

Negara Kesatuan Republik Indonesia sebagai negara kepulauan yang berciri nusantara mempunyai kedaulatan atas wilayahnya untuk dikelola dan dimanfaatkan sebesarbesarnya bagi kesejahteraan dan kemakmuran rakyat Indonesia sebagaimana diamanatkan dalam Undang-undang Dasar Negara Republik Indonesia Tahun 1945. Ruang wilayah negara meliputi ruang darat, ruang laut, dan ruang udara. Sebagai negara berdaulat, Indonesia memiliki kedaulatan penuh dan utuh atas wilayah udara, sesuai dengan ketentuan Konvensi Chicago 1944 tentang Penerbangan Sipil Internasional, Pasal 1 disebutkan bahwa "every State has complete and exclusive sovereignity over the airspace above its territory." Pasal 5 Undang-undang No. 1 Tahun 2009 tentang Penerbangan, menyebutkan negara Indonesia berdaulat penuh dan eksklusif atas wilayah udara Indonesia. Ruang udara mempunyai arti yang sangat penting bagi suatu negara, salah satunya dilihat dari aspek integritas wilayah dan keamanan nasional, yang harus di dayagunakan sebaik-baiknya.

Sebagai bagian dari kedaulatan suatu negara, ruang udara mempunyai fungsi strategis sebagai aset nasional yang sangat berharga termasuk $\begin{array}{lcc}\text { didalamnya untuk } & \text { kepentingan } \\ \text { pertahanan } & \text { dan } & \text { keamanan. }\end{array}$

Sebagaimana diketahui bahwa ruang udara nasional merupakan salah satu sumber daya alam yang terdapat di udara, dan sekaligus merupakan wilayah nasional sebagai wadah atau ruang/media, tempat Negara Kesatuan Republik Indonesia (NKRI) melaksanakan kedaulatan, hak berdaulat dan yuridiksinya. Indonesia sebagai negara berdaulat, memiliki kedaulatan yang utuh dan eksklusif terhadap ruang udara di atas wilayah NKRI, sesuai dengan ketentuan dalam Konvensi Chicago 1944 Tentang Penerbangan Sipil Internasional. Bentuk penegakan kedaulatan atas wilayah ruang udara nasional, antara lain penegakan hukum terhadap pelanggaran wilayah udara kedaulatan Republik Indonesia, dan pelanggaran terhadap kawasan udara terlarang, baik kawasan udara nasional maupun asing,

\section{Rumusan Masalah}

Berdasarkan latar belakang tersebut di atas, penulis tertarik untuk mengkaji dan menganalisis tiga permasalahan dalam penelitian yang akan ditemukan jawabannya, yaitu:

1. Bagaimana konsep kedaulatan negara di ruang udara melalui hak penguasaan negara menurut hukum internasional dan peraturan perundangan nasional? 
2. Apa saja bentuk pelanggaran kedaulatan negara di ruang udara nasional?

3. Bagaimana upaya penegakan atas pelanggaran kedaulatan dan kendala yang dihadapi?

\section{Pembahasan}

\section{Hukum Internasional yang mengatur pelanggaran kedaulatan di wilayah udara}

Dalam konteks masyarakat internasional terdapat pengakuan bahwa setiap negara mempunyai hak eksklusif dalam batas wilayah negaranya tanpa ada keterikatan atau pembatasan dari hukum internasional. Di dalam Hukum udara internasional pelanggaran batas wilayah kedaulatan di ruang udara diatur dalam Konvensi Paris 1919 dan Konvensi Chicago 1944. Dengan adanya perkembangan masyarakat internasional serta hukum internasional dan hukum udara internasional itu sendiri, maka kedaulatan negara atas ruang udara di atas wilayahnya itu tidak lagi bersifat penuh dan mutlak. Dalam hal pelanggaran kedaulatan udara suatu negara yang terjadi karena suatu hal maka guna melindungi pesawat udara sipil dari kekerasan senjata dari negara yang merasa dilanggar yang sering berakibat fatal bagi keselamatan penumpang dan awak pesawat maka Konvensi Chicago 1944 (Convention on International Civil Aviation) diubah oleh Protcol relating to an amandement to the Convention on International Civil Aviation yang ditandatangani pada tanggal 10 Mei 1984 di Montreal. Bagian yang ditambahkan dalam Konvensi Chicago 1944 adalah pasal 3 bis yang mempunyai pokok uraian ${ }^{3}$ :
1) Negara mempunyai kewajiban hukum untuk tidak menggunakan senjata terhadap pesawat udara sipil dalam penerbangannya dan di dalam hal melakukan prosedur pencegatan (interception), negara berkewajiban untuk tidak membahayakan jiwa manusia yang berada dalam pesawat, serta pesawat yang diintersepsi itu sendiri.

2) Ditetapkan bahwa sebagai perwujudan kedaulatan, negara berhak memerintahkan pesawat udara sipil yang melakukan pelanggaran wilayah udara mendarat di pelabuhan udara negara itu yang ditentukan, dalam menerapkan kewenangannya, kembali diingatkan agar negara memperhatikan ketentuan yang pertama di atas. Selain itu negara diminta untuk mengumumkan ketentuan-ketentuan yang dibuatnya dalam mengatur prosedur intersepsi terhadap pesawat udara sipil.

3) Setiap pesawat udara sipil harus mematuhi instruksi yang diberikan oleh negara yang melakukan intersepsi terhadapnya. Untuk mendukung prinsip pematuhan ini setiap negara dituntut untuk memasukkan dalam perundangundangan nasionalnya ketentuan bahwa pesawat udara sipil yang terdaftar di negaranya, akan mematuhi instruksi negara yang melakukan intersepsi kapan saja pesawat udara sipil itu mengalami kasus sedemikian. Juga dituntut agar setiap negara menetapkan dalam perundangundangan nasionalnya ketentuan 
hukuman yang berat bagi para pemilik atau operator pesawat sipil yang terdaftar di negaranya, yang melanggar prinsip pematuhan dalam menghadapi intersepsi oleh negara lain

4) Setiap negara akan mengalami tindakan-tindakan agar pesawat udara sipil yang terdaftar di negaranya, tidak dipergunakan untuk maksud yang bertentangan dengan tujuan Konvensi Chicago.

Walaupun tidak semua negara menjadi pihak atau peserta dari kedua konvensi tersebut, namun adanya pengakuan atas kedaulatan negara pada ruang udara di wilayahnya serta praktek negara-negara yang menghormati isi dari kedua konvensi tersebut dapat disimpulkan bahwa kedaulatan setiap negara atas ruang udara di wilayah (daratan maupun perairan), sudah merupakan hukum kebiasaan internasional.

\section{Penerapan Hukum Udara Nasional di Indonesia terhadap pelanggaran kedaulatan di wilayah udara Indonesia oleh pesawat sipil asing}

Negara Indonesia telah menjadi anggota Organisasi Penerbangan Sipil Internasional sejak 27 April 1950 dan telah menyempurnakan undangundang Nomor 15 Tahun 1992 dengan Undang-Undang Nomor 1 Tahun 2009 yang mengacu kepada Konvensi Chicago 1944. UndangUndang Republik Indonesia Nomor 15 Tahun 1992 tentang Penerbangan, pada Bab III Kedaulatan Atas Wilayah Udara pada Pasal 4 menyatakan bahwa Negara Republik Indonesia berdaulat penuh dan utuh atas wilayah udara Republik Indonesia yang artinya sebagai negara berdaulat, Negara Kesatuan Republik Indonesia memiliki kedaulatan penuh dan utuh di wilayah udara Republik Indonesia, sesuai dengan ketentuan Konvensi Chicago 1944 tentang Penerbangan Sipil Internasional. Selanjutnya pada Pasal 5 menyatakan bahwa dalam rangka penyelenggaraan kedaulatan negara atas wilayah udara Republik Indonesia, Pemerintah melaksanakan wewenang dan tanggung jawab pengaturan ruang udara untuk kepentingan pertahanan dan keamanan negara, penerbangan dan ekonomi nasional. Untuk menjaga kedaulatan negara Indonesia, pada awalnya negara Indonesia menggunakan Pasal 6 UndangUndang Nomor 15 Tahun 1992 menetapkan zona larangan terbang yang dianggap atas dasar pertimbangan pertahanan keamanan dan keselamatan penerbangan.

Namun disesuaikan dengan perkembangan hukum udara internasional dan perkembangan yang ada di Indonesia maka peraturan yang digunakan adalah Undang-Undang Nomor 1 Tahun 2009 pasal 6 yaitu dalam rangka penyelenggaraan kedaulatan negara atas wilayah udara, Indonesia melaksanakan wewenang dan tanggung jawab pengaturan ruang udara untuk kepentingan penerbangan, perekonomian nasional, pertahanan dan keamanan negara, sosial budayam serta lingkungan udara, karena itu pemerintah menetapkan zona larangan atau pembatasan terbang.

Beberapa contoh kasus diatas apabila terdapat pesawat udara sipil asing yang melanggar wilayah udara atau zona larangan terbang di Indonesia maka: 
1) Personel lalu lintas udara memberikan peringatan agar pesawat udara tersebut meninggalkan zona larangan atau pembatasan terbang.

2) Personel lalu lintas udara juga menginformasikan adanya pesawat udara yang melanggar zona larangan maupun pembatasan terbang kepada aparat yang bertugas di bidang pertahanan negara.

3) Apabila peringatan yang diberikan tidak ditaati maka dilakukan tindakan pemaksaan oleh pesawat udara negara (state aircraft) untuk keluar wilayah Indonesia atau pembatasan terbang untuk mendarat di pangkalan udara atau bandar udara terdekat.

4) Semua awak pesawat udara beserta muatannya diperiksa dan disidik dengan ketentuan perundang-undangan yang berlaku.

Semua prosedur diatas merupakan peraturan yang berdasarkan pada undang-undang nomor 1 tahun 2009 tentang Penerbangan pada pasal 8. Ketentuan lebih lanjut mengenai pelanggaran wilayah kedaulatan, penetapan kawasan udara terlarang, kawasan udara terbatas, pelaksanaan tindakan terhadap pesawat udara dan personel pesawat udara, serta tata cara dan prosedur pelaksanaan tindakan pemaksaan oleh pesawat udara negara diatur dengan Peraturan Pemerintah.

\section{Kendala Hukum Penindakan Terhadap Pelanggaran Kedaulatan Di Wilayah Udara Indonesia Pesawat Udara Sipil Asing Tidak Berizin}

\section{a. Kendala Penyidikan}

Dalam menangani kasus pemaksaan mendarat terhadap pesawat udara asing di wilayah Indonesia selama ini penyidikan dilakukan oleh PPNS Penerbangan yang berada di bawah Ditjen Perhubungan Udara Kementerian Perhubungan. Kewenangan PPNS ini berdasarkan pada Pasal 399 UU No. 1 Tahun 2009 tentang Penerbangan yang berbunyi pejabat pegawai negeri sipil tertentu di lingkungan instansi yang lingkup tugas dan tanggung jawabnya di bidang penerbangan diberi wewenang khusus sebagai penyidik tindak pidana sebagaimana dimaksud dalam Undang-Undang ini. Pengalaman menunjukkan, hampir semua bentuk pelanggaran wilayah udara penanganannya tidak pernah sampai pada proses peradilan. Sering dilakukan adalah penerbitan diplomatic complain kepada negara asal pelanggar tersebut.

Hal ini dilanjutkan dengan menyuruh pihak penanggung jawab untuk mengurus perizinan sebelum dilepas melanjutkan misinya. Satu dari beberapa faktor utama penyebabnya adalah dasar hukum yang belum kuat, sehingga prosedur penanganan pasca forced down, sebagai upaya derivasi dari dasar hukum tersebut, belum sempurna. Tidak seperti TNI AL, menurut undang-undang TNI AU tidak diberi kewenangan untuk menyidik. Dengan demikian, maka personil TNI AU sebagai pelaksana di lapangan hanya berwenang hingga tingkat penyelidikan saja. Menurut ketentuan yang ada saat ini, setelah proses penyelidikan dilakukan TNI AU, kasus itu diserahkan kepada PPNS penerbangan guna proses 
penyidikannya. Namun, hingga kini, proses itu belum pernah terjadi. Tentunya peradilan pun belum pernah terwujud. Absennya proses peradilan terhadap pelanggaran udara yang kerap terjadi di wilayah NKRI mengesankan kelemahan dalam penegakan hukum. Oleh karena itu, untuk memperkuat mekanisme penegakan hukum di udara wilayah NKRI, perlu dilakukan serangkaian upaya dimulai dengan pemberian kewenangan kepada TNI AU sebagai penyidik, khususnya berkaitan dengan pelanggaran wilayah. Bila kewenangan ini sudah diberikan, maka TNI AU akan menindaklanjutinya dengan penyiapan personel dan segenap perangkatnya, secara alami, akan diikuti pihak-pihak terkait lainnya. Selama ini kasus pelanggaran wilayah udara ditangani oleh PPNS bidang Penerbangan di Kementerian Perhubungan. Pemberian kewenangan hanya kepada PPNS Penerbangan ini oleh beberapa pihak dirasakan menjadi salah satu faktor penghambat dalam penegakan hukum bagi pesawat udara yang dipaksa mendarat di wilayah Indonesia. Pihak TNI AU yang melaksanakan intersepsi dan penyelidikan awal justru tidak dilibatkan dalam proses penyidikan.

\section{b. Kendala Regulasi}

Belum maksimalnya penegakan hukum terhadap pesawat udara sipil asing yang melanggar wilayah udara kedaulatan Indonesia salah satunya disebabkan tidak ada sanksi dalam peraturan perundang-undangan nasional khususnya dalam UU No. 1 Tahun 2009 tentang Penerbangan terkait pelanggaran wilayah udara (aerial instrusion). Undang-Undang tersebut hanya mengatur mengenai larangan serta denda bagi pesawat yang memasuki kawasan udara terlarang dan terbatas. Pasal $401 \mathrm{UU}$ No.1 Tahun 2009 tentang Penerbangan menyatakan setiap orang yang mengoperasikan pesawat udara Indonesia atau pesawat udara asing yang memasuki kawasan udara terlarang dipidana dengan pidana penjara paling lama 8 (delapan) tahun dan denda paling banyak Rp500.000.000,00 (lima ratus juta rupiah). Sedangkan Pasal 402 menyebutkan Setiap orang yang mengoperasikan pesawat udara Indonesia atau pesawat udara asing yang memasuki kawasan udara terbatas sebagaimana dimaksud dalam Pasal 7 ayat (4) dipidana dengan pidana penjara paling lama 3 (tiga) tahun atau denda paling banyak Rp500.000.000,00 (lima ratus juta rupiah).

Dengan norma hukum seperti tersebut diatas maka pelanggaran wilayah udara Indonesia oleh pesawat udara sipil asing tidak dapat dipidana ataupun dilanjutkan hingga ke pengadilan karena belum ada peraturan perundang-undangan nasional yang mengaturnya. Oleh sebab itu pihak Kementerian Perhubungan dalam hal ini PPNS Penerbangan melihat pelanggaran wilayah udara Indonesia hanya sebatas pelanggaran izin saja dan bukan merupakan pelanggaran terhadap kedaulatan dan keamanan bangsa. Norma hukum seperti tersebut diatas dengan belum diaturnya pelanggaran wilayah udara dalam peraturan perundang-undangan nasional itulah yang menyebabkan rendahnya denda yang diberikan kepada pelaku pelanggaran wilayah 
udara. Selama ini para pelaku hanya dikenakan denda sebesar Rp60.000.000,00 yang merupakan biaya pendaratan tambahan (landing fee) berdasarkan Pasal 17 huruf b Peraturan Direktur Jenderal Perhubungan Udara Nomor: SKEP/195/IX/2008 tentang Petunjuk Pelaksanaan Persetujuan Terbang (flight approval). Terkait masalah sanksi bagi pelaku pelanggaran, dalam peraturan terbaru PP No. 4 Tahun 2018 tentang Pamwilud sebenarnya telah diatur mengenai penerbangan tanpa izin akan dikenakan denda administratif. Disebutkan bahwa setiap orang yang melanggar ketentuan sebagaimana dimaksud, dikenakan sanksi administratif berupa denda administratif paling banyak Rp5.000.000.000,00 (lima miliar rupiah), yang dilakukan oleh menteri yang menyelenggarakan urusan pemerintahan di bidang perhubungan sesuai dengan kewenangan

c. Belum Adanya Pengaturan ADIZ Indonesia yang Baru

Salah satu kendala lain yang timbul dalam pemaksaan mendarat terhadap pesawat udara sipil asing di wilayah udara Indonesia adalah belum adanya Air Defence Identification Zone (ADIZ) yang baru. Zona Identifikasi Pertahanan Udara merupakan ruang udara tertentu di atas daratan dan/atau perairan yang ditetapkan bagi keperluan identifikasi pesawat udara untuk kepentingan pertahanan dan keamanan negara. Penetapan ADIZ yang baru ini dapat dilaksanakan berdasarkan amanat Pasal 6 PP No. 4 Tahun 2018 tentang Pamwilud yang menyatakan pemerintah dapat menetapkan Zona Identifikasi
Pertahanan Udara (ADIZ). Konsep ADIZ Indonesia yang akan ditetapkan adalah di seluruh batas wilayah udara Indonesia hingga ke laut bebas dengan mengikuti batas ZEE, meskipun secara aturan internasional batas wilayah laut ke arah luar tidak ada pembatasan serta dapat melebihi batas ZEE yang telah ditetapkan/ disepakati dengan negara tetangga. Penetapan

ADIZ yang meliputi seluruh wilayah ZEE diharapkan akan menjadi sarana identifikasi dini bagi pesawat udara asing yang akan memasuki wilayah udara Indonesia sekaligus untuk mengamankan Alur Laut Kepulauan Indonesia (ALKI), hal ini dikarenakan seluruh pesawat yang menggunakan hak lintas ALKI hanya diwajibkan untuk menaati peraturan yang ditetapkan oleh Organisasi Penerbangan Sipil Internasional (ICAO) mengenai keselamatan penerbangan dan secara rutin memonitor frekuensi radio yang ditunjuk oleh otorita pengawas lalu lintas udara yang berwenang. Dalam sistem pertahanan udara ADIZ diperlukan untuk keperluan identifikasi yang bertujuan untuk mengetahui kegiatan penerbangan suatu pesawat. ADIZ adalah suatu zona bagi keperluan identifikasi dalam sistem pertahanan udara suatu negara. Setiap pesawat udara sipil dan militer yang berada dalam zona tersebut dan akan memasuki wilayah udara nasional diharuskan memberi laporan rencana penerbangannya kepada negara yang dilalui ADIZ nya. Pelanggaran terhadap ketentuan ini dapat dikenakan tindakan berupa intersepsi oleh pesawat udara militer negara pemilik ADIZ untuk mengidentifikasi pesawat pelanggar. 
Zona tersebut terbentang mulai dari titik terluar laut teritorial negara yang bersangkutan hingga mencapai ruang udara di atas laut bebas yang berbatasan dengan wilayah negara tersebut.

Penetapan ADIZ bukan merupakan tindakan memperluas kedaulatan negara pemilik ADIZ diatas laut bebas yang tercakup dalam ADIZ negara tersebut karena ADIZ ditujukan sebagai sarana identifikasi pesawat udara yang akan memasuki wilayah tersebut.17 Setiap negara berhak menetapkan ADIZ bagi kepentingan pertahanan udara. Penetapan ADIZ di Indonesia dirasakan kurang tepat karena meliputi juga ruang udara di atas wilayah teritorial. Hal ini bertentangan dengan hakekat dan tujuan ditetapkannya ADIZ sebagai sarana identifikasi dini sebelum pesawat udara memasuki ruang udara nasioal, sedangkan apabila pesawat berada di atas wilayah teritorial tanpa izin merupakan pelanggaran wilayah udara. ADIZ untuk melakukan identifikasi pesawat udara asing seharusnya berada di luar wilayah udara teritorial nasional sehingga pesawat sebelum memasuki wilayah udara teritorial melakukan identifikasi atau melaporkan terlebih dahulu rencana penerbangannya (flight plan) untuk dapat di ketahui secara dini apabila ada ancaman terhadap wilayah Indonesia. Walaupun penetapan ADIZ di wilayah udara nasional dirasakan kurang tepat namun dalam peta navigasi internasional yang dikeluarkan ICAO, penetapan ADIZ ruang udara Indonesia dimasukkan kedalam AIP (Aeronautical Information Publication) dan telah diberitahukan ke seluruh negara. ADIZ berdasarkan AIP.

\section{Justifikasi Yuridis Kedaulatan NKRI Atas Wilayah Udara}

Berdasarkan peraturan perundangan yang berlaku di Indonesia, beberapa peraturan yang mengatur tentang penerbangan dan yang berhubungan diantaranya adalah:

a. Undang Undang No. 15 Tahun 1992 tentang Penerbangan

b. Peraturan Pemerintah No. 3 tahun 2001 tentang Keamanan dan KeselamatanPenerbangan Peraturan Pemerintah No. 70 tahun 2001 tentang Kebandarudaraan

c. Undang - Undang Republik Indonesia Nomor 37 Tahun 2002 tentang hak dan kewajiban kapal dan pesawat udara asing dalam melaksanakan hak lintas alur laut kepulauan

d. Undang-undang Penerbangan yang disahkan pada tanggal 17 Desember 2008

e. Negara Kesatuan Republik Indonesia merupakan wilayah kepulauan dengan perbandingan 2:3 antara daratan dan perairan dimana kapal dan pesawat udara asing mempunyai hak lintas untuk melintasi alur alut yang telah ditetapkan.

Hal ini sangat berpotensi terhadap pelanggaran yang dilakukan oleh pesawat udara asing karena terbukanya ruang udara diatas Alur Laut Kepulauan Indonesia (ALKI). Untuk itu diperlukan adanya UndangUndang negara untuk mengantisipasinya baik ruang udara 
di wilayah ruang udara Indonesia secara keseluruhan maupun ruang udara diatas ALKI;

a. Kedaulatan negara di ruang udara, wilayah kedaulatan, zona tambahan, ZEE dan landas kontinen;

1) Undang - Undang Republik Indonesia Nomor 15 Tahun 1992 tentang Penerbangan, pada Bab III Kedaulatan Atas Wilayah Udara pada:

a) Pasal 4 menyatakan bahwa Negara Republik Indonesia berdaulat penuh dan utuh atas wilayah udara Republik Indonesia.

Penjelasan: Sebagai negara berdaulat, Republik Indonesia memiliki kedaulatan penuh dan utuh di wilayah udara Republik Indonesia, sesuai dengan ketentuan Konvensi Chicago 1944 tentang Penerbangan Sipil Internasional. Ketentuan dalam pasal ini hanya menegaskan mengenai kewenangan dan tanggung jawab negara Republik Indonesia untuk mengatur penggunaan wilayah udara yang merupakan bagian dari wilayah dirgantara Indonesia sedangkan mengenai kedaulatan atas wilayah Republik Indonesia secara menyeluruh tetap berlaku ketentuan sebagaimana diatur dalam Undangundang Nomor 20 Tahun 1982 tentang Ketentuan Pokok Pertahanan Keamanan Negara Republik Indonesia. Pasal 5 menyatakan bahwa dalam rangka penyelenggaraan kedaulatan negara atas wilayah udara Republik Indonesia, Pemerintah melaksanakan wewenang dan tanggung jawab pengaturan ruang udara untuk kepentingan pertahanan dan keamanan negara, penerbangan dan ekonomi nasional.

Penjelasan: Wilayah udara yang berupa ruang udara di atas wilayah daratan dan perairan Republik Indonesia merupakan kekayaan nasional sehingga harus dimanfaatkan bagi sebesar-besar kepentingan rakyat, bangsa dan Negara; Pasal 6 menyatakan bahwa:

(1) Untuk kepentingan pertahanan dan keamanan negara serta keselamatan penerbangan, Pemerintah menetapkan kawasan udara terlarang. Penjelasan: Kewenangan menetapkan kawasan udara terlarang merupakan kewenangan dari setiap negara berdaulat untuk mengatur penggunaan wilayah udaranya, dalam rangka pertahanan keamanan negara dan keselamatan penerbangan. Kawasan udara terlarang dalam ketentuan ini mengandung dua pengertian yaitu:

a. Kawasan udara terlarang yang larangannya bersifat tetap (prohibited area) karena pertimbangan pertahanan dan keamanan negara serta keselamatan penerbangan.

b. Kawasan udara terlarang yang larangannya bersifat terbatas (restricted area) karena pertimbangan pertahanan keamanan dan keamanan atau keselamatan penerbangan atau kepentingan umum misalnya pembatasan ketinggian terbang, pembatasan waktu operasi dan lain lain.

c. Pesawat udara Indonesia atau pesawat udara asing dilarang terbang melalui kawasan udara terlarang dan terhadap pesawat udara yang melanggar larangan dimaksud dapat dipaksa untuk mendarat di pangkalan udara atau 
Bandar udara di dalam wilayah Republik Indonesia.

d. Penjelasan: Penegakan hukum terhadap ketentuan ini dilakukan dengan menggunakan pesawat udara Angkatan Bersenjata Republik Indonesia oleh instansi yang bertanggungjawab di bidang pertahanan dan keamanan. Pasal 7 menyatakan:

1. Fungsi ruang udara sebagai wilayah kedaulatan, batas ketinggian ruang udara nasional sampai 110 (seratus sepuluh) kilometer dari permukaan laut di atas wilayah Negara Kesatuan Republik Indonesia. Penetapan batas ruang udara nasional sampai ketinggian 110 (seratus sepuluh) kilometer dari permukaan laut didasarkan pada sifat fisik ruang udara dan antariksa. Penetapan batas ruang udara nasional merupakan wujud dari pelaksanaan Pasal 25A Undangundang Dasar Republik Indonesia Tahun 1945;

2. Fungsi ruang udara sebagai lingkungan, merupakan ruang atau wadah bagi keberlang-sungan hidup manusia dan makhluk hidup lainnya;

3. Fungsi ruang udara untuk kepentingan sosial dan ekonomi, pemanfaatannya ditujukan untuk kemakmuran rakyat serta pertahanan negara. Fungsi ruang udara untuk kepentingan sosial dan ekonomi, antara lain untuk:

a. Penerbangan sebagai media penerbangan, alur atau pelintasan penerbangan, dan media telekomunikasi berkenaan penerbangan; b. Telekomunikasi sebagai media jaringan telekomonikasi, sarana telekomunikasi, dan jalur dan jaringan telekomunikasi;

c. Frekuensi sebagai media jaringan frekuensi;

d. kenavigasian sebagai media kenavigasian untuk sarana bantu navigasi, telekomunikasi pelayaran, hidrologi, alur atau pelintasan, pemandu keselamatan pelayaran;

e. Sumber energi listrik dan sebagai media untuk jaringan listrik;

f. Industri sebagai bahan baku utama dan/atau penolong industri;

g. Pengembangan ilmu pengetahuan sebagai sarana dan prasarana laboratorium ruang udara;

h. Pendidikan sebagai media untuk menunjang sarana dan prasarana dalam pelaksanaan proses belajar jarak jauh;

i. Pemetaan sebagai media untuk kegatan pemetaaan tentang kondisi daratan dan perairan;

j. Perekaman udara sebagai media untuk kegiatan perekaman untuk mendapatkan data dan informasi keadaan ruang udara nasional, daratan, dan perairan;

k. Survei sebagai media untuk melakukan survei dari udara berkenaan dengan kegiatan penelitian yang dilakukan di udara;

1. Pengindaraan jauh sebagai media untuk pengindaraan 
jauh tentang keadaan geologi, geodesi, topografi pertanian, kehutanan, dan perikanan laut;

m. Bangunan dan bangunan gedung, sebagai media untuk berdirinya bangunan jembatan, bangunan gedung, menara, dan sejenisnya;

n. Pemantauan dan/atau perubahan cuaca, sebagai media untuk melakukan pemantauan dan/atau perubahan cuara tentang keadaan cuaca dan/atau perkembangannya;

o. Olahraga udara sebagai media untuk melakukan kegiatan olahraga udara;

p. Wisata udara sebagai media untuk kegiatan wisata udara; periklanan.

(4) Ketentuan mengenai penetapan kawasan udara terlarang dan tindakan pemaksaan sebagaimana dimaksud dalam ayat (1) dan ayat (2) diatur lebih lanjut dengan Peraturan Pemerintah.

Kedaulatan negara ruang udara diatas ALKI Undang - Undang Republik Indonesia Nomor 37 Tahun 2002 tentang hak dan kewajiban kapal dan pesawat udara asing dalam melaksanakan hak lintas alur laut kepulauan yang ditetapkan :

Pasal 4 menyatakan bahwa:

a. Kapal dan pesawat udara asing yang melaksanakan Hak Lintas Alur Laut Kepulauan harus melintas secepatnya melalui atau terbang di atas alur laut kepulauan dengan cara normal, sematamata untuk melakukan transit yang terus-menerus, langsung, cepat, dan tidak terhalang. b. Kapal atau pesawat udara asing yang melaksanakan lintas alur laut kepulauan, selama melintas tidak boleh menyimpang lebih dari 25 (dua puluh lima) mil laut ke kedua sisi dari garis sumbu alur laut kepulauan, dengan ketentuan bahwa kapal dan pesawat udara tersebut tidak boleh berlayar atau terbang dekat ke pantai kurang dari 10 $\%$ (sepuluh per seratus) jarak antara titiktitik yang terdekat pada pulau-pulau yang berbatasan dengan alur laut kepulauan tersebut.

c. Kapal dan pesawat udara asing sewaktu melaksanakan Hak Lintas Alur Laut Kepulauan tidak boleh melakukan ancaman atau menggunakan kekerasan terhadap kedaulatan, keutuhan wilayah, atau kemerdekaan politik Republik Indonesia, atau dengan cara lain apapun yang melanggar asas-asas Hukum Internasional yang terdapat dalam Piagam Perserikatan Bangsa-Bangsa.

d. Kapal perang dan pesawat udara militer asing, sewaktu melaksanakan Hak Lintas Alur Laut Kepulauan, tidak boleh melakukan latihan perang-perangan atau latihan menggunakan senjata macam apapun dengan mempergunakan amunisi.

e. Kecuali dalam keadaan force majeure atau dalam hal musibah, pesawat udara yang melaksanakan Hak Lintas Alur Laut Kepulauan tidak 
boleh melakukan pendaratan di wilayah Indonesia.

f. Semua kapal asing sewaktu melaksanakan Hak Lintas Alur Laut Kepulauan tidak boleh berhenti atau berlabuh jangkar atau mondar-mandir, kecuali dalam hal force majeure atau dalam hal keadaan musibah atau memberikan pertolongan kepada orang atau kapal yang sedang dalam keadaan musibah.

g. Kapal atau pesawat udara asing yang melaksanakan Hak Lintas Alur Laut Kepulauan tidak boleh melakukan siaran gelap atau melakukan gangguan terhadap sistem telekomunikasi dan tidak boleh melakukan komunikasi langsung dengan orang atau kelompok orang yang tidak berwenang dalam wilayah Indonesia.

Pasal 8 menyatakan bahwa:

a) Pesawat udara sipil asing yang melaksanakan Hak Lintas Alur Laut Kepulauan harus:

(1) Menaati peraturan udara yang ditetapkan oleh Organisasi Penerbangan Sipil Internasional mengenai keselamatan penerbangan;

2) Setiap waktu memonitor frekuensi radio yang ditunjuk oleh otorita pengawas lalu lintas udara yang berwenang yang ditetapkan secara internasional atau frekuensi radio darurat internasional yang sesuai.

b) Pesawat udara negara asing yang melaksanakan Hak Lintas Alur Laut Kepulauan harus:
(1) Menghormati peraturan udara mengenai keselamatan penerbangan sebagaimana dimaksud dalam ayat (1) huruf $\mathrm{a}$

(2) Memenuhi kewajiban sebagaimana dimaksud dalam ayat (2) huruf (a) dalam menegakkan kedaulatan dan hukum terhadap pelanggaran wilayah udara nasional, TNI Angkatan Udara mempunyai wewenang dan tanggung jawab untuk melakukannya.

Untuk penerapan tugas dan tanggung jawab tersebut Komando Pertahanan Udara Nasional (KOHANUDNAS) bertindak sebagai pelaksana operasi pertahanan udara aktif dan operasi pertahanan udara pasif. Sesuai dengan Pasal 10 UU No 34 Tentang Tentara Nasional Indonesia yaitu:

a. Melaksanakan tugas TNI matra udara dibidang pertahanan

b. Menegakkan hukum dan menjaga keamanan wilayah udara yuridiksi nasional sesuai dengan ketentuan hukum nasional dan hukum internasional yang telah diratifikasi

c. Melaksanakan tugas TNI dalam pembangunan dan pengembangan kekuatan matra udara d. Melaksanakan pemberdayaan wilayah pertahanan udara.

Undang-undang Penerbangan yang disahkan pada tanggal 17 Desember 2008 sangat menjanjikan terhadap pertumbuhan transportasi udara di Indonesia, karena undangundang tersebut secara komprehensif mengatur pengadaan pesawat udara sebagaimana diatur dalam konvensi 
Cape Town 2001. Berlakunya undang-undang tersebut maka kedaulatan secara extra-teritorial atas wilayah udara Indonesia, pelanggaran wilayah kedaulatan yang lebih dipertegas. Persoalan utama yang diatur dalam UU dimaksud mencakup: Produksi pesawat udara, pendaftaran dan kebangsaan pesawat udara, kelaik-udaraan dan pengoperasian pesawat udara, keselamatan dan keamanan di dalam pesawat udara, asuransi pesawat udara, independensi investigasi kecelakaan pesawat udara, pembentukan majelis profesi penerbangan, lembaga penyelenggara pelayanan umum yang sering disebut badan pelayan umum (BLU). Pengadaan pesawat udara sebagaimana diatur di dalam Konvensi Cape Town 2001, berbagai jenis angkutan udara baik niaga maupun bukan niaga dalam negeri maupun luar negeri, kepemilikan modal harus single majority, tetap berada pada warga negara Indonesia. Syarat pengoperasian setiap perusahaan penerbangan menurut UU tersebut, minimum mempunyai 10 (sepuluh) pesawat udara, 5 lima dimiliki dan 5 dikuasai (leasing). Hal lain yang menjadi konsen pengaturan dalam UU tersebut sebgai manifestasi dari pelaksanaan kedaulatan Negara atas wilayah udara meliputi : komponen tarif yang dihitung berdasarkan tarif jarak, pajak, iuran wajib asuransi dan biaya tambahan, pelayanan bagi penyandang disabilitas, pengangkutan barangbarang berbahaya (dangerous goods), ekspedisi dan keagenan, tanggung jawab pengangkut, konsep tanggung jawab pengangkut, asuransi tanggung jawab pengangkut, tanggung jawab pengangkut terhadap pihak ketiga (third parties liability), tatanan kebandarudaraan baik lokasi maupun persyaratannya, obstacles, perubahan iklim yang menimbulkan panas bumi, sumber daya manusia baik di bidang operasi penerbangan, teknisi bandar udara maupun navigasi penerbangan, fasilitas navigasi penerbangan, otoritas bandar udara, pelayanan bandar udara, keamanan penerbangan, lembaga penyelenggara pelayanan navigasi penerbangan (single air service provider), penegakan hukum, penerapan sanksi administratif yang selama ini tidak diatur, budaya keselamatan penerbangan, penanggulangan tindakan melawan hukum dan berbagai ketentuan baru guna mendukung keselamatan transportasi udara nasional maupun internasional.

Konsep Kedaulatan Negara di Ruang Udara Menurut Hukum Internasional dan Peraturan Perundangan Nasional

a. Kedaulatan Negara di Ruang Udara Menurut Hukum Internasional

Norma hukum internasional yang dijadikan rujukan adalah perjanjian internasional yang berpengaruh dan mengikat Indonesia, yaitu Konvensi Chicago 1944 tentang Penerbangan Sipil Internasional (International Civil Aviation). Sebelum membahas Konvensi Chicago 1944, kurang tepat apabila tidak meninjau aturan sebelumnya yaitu Konvensi Paris 1919. Dalam Pasal 1 dinyatakan bahwa "the high contracting parties recognize that every power has the complete and exclusive sovereignty over the airspace above its territory". 
Konsekuensi dari pasal tersebut, negera peserta konvensi dapat melakukan pembatasan penerbangan pesawat udara lain yang bukan peserta konvensi, sebagaimana diatur dalam Pasal 5 konvensi. Dalam perjalanannya, Konvensi Paris 1919 mulai ditinggalkan dan masyarakat internasional membentuk Konvensi Chicago 1944 di mana masalah kedaulatan kembali diatur dalam konvensi ini. Di dalam bagian pembukaan (preambule) disebutkan bahwa lahirnya konvensi ini didasarkan pada semangat untuk melestarikan hubungan persahabatan antar negara dalam pengelolaan penerbangan sipil dan ruang udara dan menghindari terjadinya konflik antar negara yang merusak perdamaian dunia. Di samping itu, konvensi lahir didasarkan adanya potensi ekonomi yang dimiliki oleh negara-negara pada wilayah udara. Sejalan dengan pertimbangan tersebut diatas, maka konvensi didasarkan pada prinsip kedaulatan di ruang udara yang selengkapnya pada Pasal 1 Konvensi Chicago 1944 berbunyi "the contracting states recognize that every state has complete and exclusive sovereignty over the airspace above its territory".

Ketentuan ini merupakan salah satu tiang pokok hukum internasional yang mengatur ruang udara (airspace). Pengaruh prinsip ini kemudian diikuti dalam Kitab Undang-Undang hukum Perdata (KUHPdt) dalam Pasal 571-nya. Sifat kedaulatan negara di udara yang bersifat complete and exclusive merupakan pembeda dengan kedaulatan negara laut territorial. Karena sifatnya yang demikian, maka di ruang udara tidak dikenal hak lintas damai (innocent passage) bagi pihak asing, sementara di laut territorial dibatasi dengan hak negara lain untuk melakukan hak lintas damai. Ruang udara suatu negara sepenuhnya tertutup bagi pesawat udara asing, baik sipil maupun militer. Dari prinsip kedaulatan negara di wilayah udara sebagaimana tercantum dalam Pasal 1 Konvensi Chicago 1944 di atas, terdapat dua hal penting untuk dilakukan pembahasan dan pemahaman, yaitu (1) penuh dan utuh (complete and exclusive), dan (2) ruang atau wilayah udara (airspace). Pada prinsipnya, setiap negara di dalam wilayah kedaulatannya mempunyai hak untuk menjalankan, memaksakan serta menyelesaikan perkara-perkara yang terjadi atas orang, benda, dan berbagai permasalahan lainnya berdasarkan peraturan perundangan nasionalnya. Namun kekuasaan tersebut tidaklah begitu absolut sehingga tidak dapat begitu saja mengesampingkan kepentingan negara-negara lain. Oleh karena itu, kedaulatan yang penuh dan utuh tersebut juga harus menghormati ketentuan-ketentuan yang telah diatur dalam hukum internasional. Dalam hal ini, harus memperhatikan ketentuan hukum internasional khususnya Attachment dari Annex 2 tentang Rule of Air. Dalam annex ini dikenal adanya asas pertimbangan dasar kemanusiaan (elementary considerations of humanity) di mana secara tegas telah dinyatakan sebagai asas yang melandasi tindakan-tindakan negara dalam menghadapi pelanggaran wilayah udaranya oleh pesawat udara sipil asing. Mengenai batas wilayah udara, tidak disebutkan baik di dalam Konvensi Paris 1919 maupun 
Konvensi Chicago 1944.2. Kedaulatan Negara di Ruang Udara Menurut Peraturan Perundangan Nasional Pengaturan kedaulatan negara di wilayah udara dalam hukum nasional penting untuk dikaji dalam upaya untuk memahami bagaimana hukum nasional mengatur hal ini terutama Undang-Undang Dasar Negara Republik Indonesia Tahun 1945 dan peraturan perundangundangan di bawahnya terutama Undang-Undang No. 43 Tahun 2008 tentang Wilayah Negara dan UndangUndang No. 1 Tahun 2009 tentang Penerbangan.

\section{b. Kedaulatan Negara di Wilayah Udara dalam Konstitusi \\ Konstitusi dalam sistem} peraturan perundang-undangan sebuah negara merupakan norma hukum yang paling tinggi tingkatannya yang menjadi rujukan bagi pembentukan peraturan perundang-undangan di bawahnya. Konstitusi dianggap sebagai sumber tertulis dimana dikonstruksikan dalam naskah tertulis sebenarnya yang bertujuan mewujudkan tripartite tujuan hukum, yaitu kepastian hukum, kemanfaatan hukum, dan keadilan. Termasuk di dalam konstitusi tertulis Indonesia diatur tentang wilayah negara di mana di dalam Undang-Undang Dasar Negara Republik Indonesia Tahun 1945 terdapat dua pasal yang mengatur hal tersebut, yaitu Pasal 25 A yang mengatur tentang wilayah negara dan Pasal 33 ayat (3). Dalam Pasal 25 A disebutkan bahwa "Negara Kesatuan Republik Indonesia adalah sebuah negara kepulauan yang bercirikan nusantara". Hukum internasional melalui Konvensi Chicago 1944 dan Konvensi Hukum Laut (UNCLOS)
1982 mengakui kedaulatan negara atas wilayah darat, laut dan udara. Namun Pasal 33 ayat (3) hanya mengatur penguasaan negara atas wilayah darat (bumi) dan laut (air) saja. Absennya pengaturan wilayah udara dalam konstitusi memiliki konsekuensi logis bahwa kekayaan alam yang terkandung di ruang udara tidak dikuasai oleh negara. Ini merupakan cerminan ketidaksadaran para perumus konstitusi akan arti penting dan peran strategis ruang udara di atas wilayah suatu negara, baik secara politik, ekonomi, sosial budaya dan pertahanan keamanan. Yang lebih mengherankan, ketika terjadi perubahan konstitusi dengan beberapa amandemennya, ketentuan pasal ini tidak mengalami perubahan sedikitpun.

\section{Pengaturan Kedaulatan Negara di Ruang Udara dalam Undang- Undang No. 43 Tahun 2008 tentang Wilayah Negara}

Pengaturan wilayah negara dalam undang-undang ini merupakan amanat Pasal 25 Undang-Undang Dasar Negara Republik Indonesia Tahun 1945 di mana dikukuhkan kembali pengakuan hukum internasional atas kedaulatan negara atas wilayah udara, darat, dan laut dalam berbagai perjanjian internasional. Dalam penjelasan umum disebutkan bahwa "Wilayah udara adalah salah satu unsur negara yang merupakan satu kesatuan wilayah daratan, perairan pedalaman, perairan kepulauan, dan laut teritorial beserta dasar laut dan tanah dibawahnya, serta ruang udara diatasnya". Sedangkan dalam Pasal 3 disebutkan bahwa "Pengaturan wilayah negara dalam undang- 
undang ini bertujuan untuk: a) menjamin keutuhan wilayah negara, kedaulatan negara, dan ketertiban di kawasan perbatasan; b) menegakkan kedaulatan dan hak-hak berdaulat; dan c) mengatur pengelolaan dan pemanfaatan wilayah negara dan kawasan perbatasan, termasuk pengawasan batas-batasnya".

Dalam Pasal 4 disebutkan bahwa "wilayah negara meliputi wilayah darat, wilayah perairan, dasar laut, dan tanah di bawahnya serta ruang udara di atasnya, termasuk seluruh sumber kekayaan yang terkandung di dalamnya". Pasal 6 ayat (1) huruf (c) menjelaskan "batas wilayah di udara mengikuti batas kedaulatan negara di darat dan di laut, dan batasnya dengan angkasa luar ditetapkan berdasarkan perkembangan hukum internasional". Sedangkan dalam Pasal 10 ayat (1) huruf (e) disebutkan "dalam pengelolaan wilayah negara dan kawasan perbatasan, pemerintah berwenang memberikan izin kepada penerbangan internasional untuk melintasi wilayah udara teritorial pada jalur yang telah ditentukan dalam peraturan perundangundangan".

\section{Pengaturan Kedaulatan Negara dalam Undang-Undang No. 1 Tahun 2009 tentang Penerbangan}

Sebelum diundangkannya Undang-Undang No. 1 Tahun 2009 tentang Penerbangan, pengaturan tentang penerbangan terlebih dahulu diatur dalam Undang-Undang No. 83 Tahun 1958 dan Undang-Undang No. 15 Tahun 1992. Pengaturan kedaulatan negara dalam UndangUndang No. 83 Tahun 1958 tidak diatur secara eksplisit (tegas), tetapi secara implisit (tak langsung) dapat dimaknai sebagai bentuk kedaulatan negara di ruang udara. Di mana dinyatakan dalam Pasal 2 yang menyebutkan bahwa "Dilarang melakukan penerbangan selainnya dengan pesawat udara yang mempunyai kebangsaan Indonesia, atau dengan pesawat udara asing berdasarkan perjanjian internasional atau persetujuan pemerintah" dan Pasal 5 ayat (1) yang berbunyi "Menteri dan/atau Menteri Pertahanan berkuasa untuk melarang penerbangan di atas suatu bagian wilayah Republik Indonesia dengan tidak membedakan antara pesawat udara Indonesia dan asing". Berbeda dengan Undang-Undang No. 83 Tahun 1958, pada UndangUndang No. 15 Tahun 1992 mengatur secara khusus kedaulatan negara di wilayah udara dalam satu bab khusus.

Dalam Pasal 4 menyebutkan bahwa "Negara Republik Indonesia berdaulat penuh dan utuh atas wilayah ruang udara Republik Indonesia". Prinsip kedaulatan negara yang bersifat complete and exclusive yang ada dalam Konvensi Chicago 1944 diterapkan dalam undang-undang ini dengan mengartikan complete and exclusive dengan istilah penuh dan utuh. Sebagai bentuk pengejawantahan kedaulatan negara yang penuh dan utuh tersebut, dalam Pasal 5 disebutkan bahwa "Dalam rangka penyelenggaraan kedaulatan negara atas wilayah udara Republik Indonesia, pemerintah melaksanakan wewenang dan tanggung jawab pengaturan ruang udara untuk kepentingan pertahanan dan keamanan negara, penerbangan, dan ekonomi nasional". Selanjutnya, terkait kedaulatan negara di ruang 
udara dalam UndangUndang No. 1 Tahun 2009 diatur secara khusus dalam Pasal 5 yang menyatakan bahwa "Negara Kesatuan Republik Indonesia berdaulat penuh dan eksklusif atas wilayah udara Republik Indonesia". Diharapkan dalam undang-undang khusus tersebut dapat memuat ketentuan-ketentuan tentang:

1) Batas-batas wilayah kedaulatan negara di ruang udara;

2) Penentuan wilayah udara di atas ALKI;

3) Wewenang dan tanggung jawab terhadap wilayah udara;

4) Pertahanan udara;

5) Operasi-operasi udara yang harus dilaksanakan;

6) Koordinasi antara pertahanan udara dan penerbangan sipil;

7) Ketentuan tentang penyidik apabila terjadi pelanggaran di wilayah udara.

\section{Bentuk Pelanggaran Kedaulatan Negara di Ruang Udara Nasional}

Pelanggaranya didorong oleh adanya kesadaran negara-negara akan sifat khusus dari potensi penggunaan pesawat udara sebagai alat utama sistem senjata teknologi. Dari reportase Republika tanggal 13 Nopember 2014, pelanggaran atas wilayah Indonesia tercatat pertama kali terjadi pada tanggal 2 Juli 2003 ketika lima pesawat militer F-18 Hornet milik Amerika Serikat melintasi pulau Bawean tanpa izin. Pesawat temput TNI-AU kita lalu mengejar dan memperingatkan mereka hingga pergi keluar dari udara Indonesia. Sembilan tahun kemudian, pada bulan Juni 2011 pesawat angkut C17 Globe Master pernah masuk ke wilayah Indonesia tanpa izin. Pesawat angkut raksasa itu masuk lewat
Pekanbaru, Riau. Pesawat dihalau keluar hingga ke Morotai. Selanjutnya, pelanggaran izin melintas terjadi empat kali pada tahun 2014. Pesawat asing melintas di Sumatera Utara. Pertama, pesawat yang hanya berisi satu pilot asal Swedia itu dipaksa turun di Lanud Soewondo Medan (14 April 2014). Kedua, pesawat asing yang diawaki dua pilot asal Australia terbang tanpa izin di Manado dan dipaksa turun ke Lanud Sam Ratulangi, Manado (22 Oktober 2014). Ketiga, satu pesawat militer Singapura dipaksa mendarat di Lanud Supadio, Pontianak, saat melintas wilayah Kalimantan (28 Oktober 2014). Dan terakhir, satu pesawat Saudi Arabia Airlines dipaksa mendarat di Bandara El Tari, Kupang (3 November 2014). faktor Peyebab Adanya Pelanggaran TKI di lokasi kejadian. Dengan memperhatikan dan mempelajari sejumlah insiden pelanggaran izin masuk dan melintasnya pesawatpesawat asing ke wilayah udara Indonesia, di mana kebanyakan dari pesawat asing tersebut adalah pesawat militer, maka dapat diindentifikasikan bahwa masalahnya bermuara kepada tiga hal, yaitu :

1. Pesawat negara-negara tetangga sering kali melanggar wilayah udara Indonesia dengan mendalilkan atau mendasarkan bahwa yang melanggar bukan pilot yang mengemudikannya, tetapi operator pesawat dari maskapai yang bersangkutan dalam kedudukannya sebagai pemilik pesawat tersebut. Hal ini dikarenakan pilot hanya menjalankan perintah untuk mengemudikan pesawat. Konsekuensi dari masalah ini 
berakibat kepada sulitnya menjatuhkan sanksi kepada personal, karena pihak operatornya adalah badan hukum asing yang berada di luar yurisdiksi dan wilayah teritorial Indonesia.

2. Sanksi denda yang terlalu kecil yaitu sebesar Rp 60 juta terhadap pelanggaran atas wilayah udara di Indonesia oleh pesawat asing, meskipun ancaman hukuman pada Pasal 414 Undang-Undang No. 1 Tahun 2009 sesungguhnya cukup tinggi. Pasal tersebut berbunyi bahwa "Setiap orang yang mengoperasikan pesawat udara asing di wilayah Negara RI tanpa izin Menteri sebagaimana dimaksud dalam Pasal 63 ayat (2) undang-undang ini dapat dipidana dengan pidana penjara paling lama 5 tahun atau denda paling banyak $\mathrm{Rp} 2$ miliar rupiah". Artinya, yang terjadi di lapangan adalah sanksi denda yang tidak maksimal di dalam menjatuhkan hukumannya. Sementara itu, biaya operasional pesawat Sukhoi yang harus dikeluarkan TNI-AU dalam rangka melakukan pengejaran pesawat asing menghabiskan anggaran US\$ 20 ribu atau sekitar Rp 240 juta per jam. Sehingga terjadi ketidakseimbangan biaya antara biaya pengejaran yang dilakukan oleh TNI-AU dengan sanksi denda yang dikenakan oleh Kementerian Perhubungan.

3. Kewenangan penyidikan untuk penanganan perkara pelanggaran izin pesawat terbang asing yang melintasi wilayah Indonesia adalah Penyidik PNS dari
Kementerian Perhubungan sesuai dengan Pasal 399 dan 400 dari UndangUndang No. 1 Tahun 2009 tentang Penerbangan. Ketentuan ini mempersulit di dalam penanganannya, karena TNI-AU yang melakukan pengejaran, sementara hukumannya diberikan oleh Kementerian Perhubungan. Hal ini menandakan adanya dualisme dalam penanganannya, sehingga terbuka perbedaan dalam menghadapi dan menyelesaikan permasalahan ini oleh TNI-AU dan Kementerian Perhubungan.

\section{Upaya Penegakan atas Pelanggaran Kedaulatan Negara di Ruang Udara Nasional dalam Menjaga Pertahanan Negara}

Terhadap pelanggaran wilayah udara Republik Indonesia dan atau kawasan udara terlarang oleh pesawat udara sipil, dilaksanakan penegakan hukum yang harus menjamin keselamatan dan keamanan awak pesawat, penumpang dan pesawat udara. Penegakan hukum terhadap pelanggaran wilayah udara dan/atau kawasan udara terlarang sebagaimana dimaksud di atas dilakukan dengan suatu operasi pertahanan udara oleh TNI-AU.19 Berdasarkan Aeronautical Information Publication (AIP) Indonesia, ditetapkan bahwa area yang menjadi area udara terlarang hanya WRP 23 Balikpapan. Namun demikian, pada kenyataannya ruang udara nasional diatur oleh aturanaturan internasional yang tidak sesuai dengan kehendak kita sebagai negara kepulauan (archipelagic state). Konvensi PBB tentang Hukum Laut Tahun 1982 pada Pasal 53 diatur 
bahwa negara kepulauan seperti Indonesia dapat menentukan alur laut dan rute penerbangan di atasnya. Semua kapal dan pesawat udara dapat menikmati hak lintas alur laut kepulauan dalam alur laut dan rute penerbangan. Dari ketentuan konvensi tersebut terlihat bahwa ruang udara nasional dipecah-pecah dalam Alur Laut Kepulauan Indonesia (ALKI) I, ALKI II dan ALKI III dan tanggung jawabnya dibagi-bagi, sehingga ruang udara yang dipecah-pecah tersebut tidak dapat dikendalikan. Sementara itu, negara maju seperti Amerika Serikat pada kenyataannya belum meratifikasi Konvensi Hukum Laut Tahun 1982 (UNCLOS 1982), padahal negara lain sudah banyak yang meratifikasi, sehingga bila Amerika Serikat melintas perairan dan wilayah udara nasional Indonesia masih berpedoman kepada aturanaturan yang lama, seperti Traditional Route for Navigation. Oleh karena itu, untuk kepentingan pertahanan dan keamanan, diperlukan peningkatan status beberapa area udara dari restricted area menjadi prohibited area.

\section{Simpulan}

Prinsip-prinsip hukum udara internasional terkandung ataupun tertuang dalam Konvensi Hukum Udara Internasional dari waktu ke waktu berkembang. Konvensikonvensi tersebut muncul dari konferensi Internasional yang dilakukan negara-negara didunia yang menganggap perlu adanya aturan-aturan yang mengatur tentang ruang udara (space). Dengan memperhatikan sejumlah insiden pelanggaran masuk dan melintasnya pesawat-pesawat asing ke wilayah udara Indonesia, di mana kebanyakan dari pesawat asing tersebut adalah pesawat militer, maka dapat diindentifikasikan bahwa masalahnya bermuara kepada tiga hal, yaitu (a) sulitnya penjatuhan sanksi kepada personal (pilot), karena pihak operatornya adalah badan hukum asing yang berada di luar yurisdiksi dan wilayah teritorial Indonesia, (b) sanksi denda yang terlalu kecil yang mengakibatkan terjadinya ketidakseimbangan biaya antara biaya pengejaran yang dilakukan oleh TNI-AU dengan sanksi denda yang dikenakan oleh Kementerian Perhubungan, dan (c) adanya dualisme dalam penanganan perkara pelanggaran izin terbang pesawat asing, sehingga terbuka perbedaan dalam menghadapi dan menyelesaikan permasalahan ini oleh TNI-AU dan Kementerian Perhubungan.3. Upaya penegakan atas pelanggaran kedaulatan di wilayah ruang udara nasional, antara lain penegakan hukum terhadap pelanggaran wilayah udara kedaulatan Republik Indonesia dan pelanggaran terhadap kawasan udara terlarang, baik kawasan udara nasional maupun asing, sebagaimana ditetapkan dalam pasal 2 ayat (2) Undang-Undang No. 15 Tahun 1992 tentang Penerbangan dan Peraturan Pemerintah No. 3 Tahun 2001 tentang Keamanan dan Keselamatan Penerbangan. Namun, pada kenyataannya ruang udara nasional diatur oleh aturan-aturan internasional yang tidak sesuai dengan kehendak Indonesia sebagai negara kepulauan, di mana sering terjadi benturan aturan antara Indonesia yang sudah meratifikasi 
UNCLOS 1982 dengan negaranegara lain yang belum meratifikasi konvensi tersebut, seperti Amerika Serikat.

\section{Saran}

Masalah pengawasan dan keamanan lalu lintas udara dan pengamanan atas pesawat-pesawat udara merupakan aspek penting dalam pengaturan hukum yang dibuat oleh suatu negara. Karena itu setiap negara berdaulat, perlu mengembangkan dan menbangun sistem regulasi yang efektif dalam pengawasan keamanan lalu lintas udara masing masing Negara berdaulat. Sudah saatnya regulasi tentang FIR dilakukan revisi dengan mengadopsi unsur-unsur kepentingan kedaulatan negara meski tetap menjamin keamanan dan keselamatan penerbangan. Hal tersebut sangat diperlukan dalam upaya penegakan kedaulatan dan keamanan negara di wilayah udara. Selain itu, peranan pemerintah dalam menciptakan peraturan perundang-undangan yang menjamin adanya kepastian hukum dan reformasi birokrasi di bidang penerbangan melalui penegakan hukum yang konsisten, dapat meningkatk

\section{Daftar Pustaka}

Agus Riyanto, 2015. "Mengakhiri Dualisme dalam Menjaga dan Menangani Wilayah Udara Indonesia", Makalah disampaikan dalam 5th Dies Natalis Business Law, Jakarta: Universitas Bina Nusantara.

E. Saefullah Wiradipradja. 2014. Pengantar Hukum Udara dan Ruang Angkasa Buku I, Bandung: PT. Alumni.
Jimly Ashiddiqie, 2004. Pengantar Hukum Tata Negara Jilid I, Jakarta: Konstitusi Press.

Markas Besar TNI-AU. 2003. Buku Petunjuk Pelaksanaan OPSGAB tentang Operasi Hanud Nasional, Jakarta: tanpa penerbit.

Mochtar Kusumaatmadja. 2003.

Konsepsi Hukum Negara

Nusantara pada Konferensi Hukum Laut 1982, Bandung: PT. Alumni.

Widarto, T. Bambang. (2015). Tinjauan Hukum Udara

Sebagai Pengantar (Dalam Perspektif Hukum Internasional dan Nasional). Jakarta: Sekolah Tinggi Hukum Militer

Wiradipradja, E. Saefullah. (2014). Pengantar Hukum Udara dan Ruang Angkasa. Buku I Hukum Udara. Bandung: Alumni

Yasidi Hambali, 1994, Hukum dan Politik Kedirgantaraan, Jakarta: Pradnya Paramita.

Mangku, D. G. S. (2010). Pelanggaran terhadap Hak Kekebalan Diplomatik (Studi Kasus Penyadapan Kedutaan Besar Republik Indonesia (KBRI) di Yangon Myanmar berdasarkan Konvensi Wina 1961). Perspektif, 15(3).

Mangku, D. G. S. (2011). Peluang dan Tantangan ASEAN Dalam Penyelesaian Sengketa Kuil Preah Vihear Di Perbatasan Kamboja dan Thailand. Pandecta: Research Law Journal, 6(2). Mangku, D. G. S. (2012). Suatu Kajian Umum tentang 
Penyelesaian Sengketa Internasional Termasuk di Dalam Tubuh ASEAN. Perspektif, 17(3).

Mangku, D. G. S. (2013). Kasus Pelanggaran Ham Etnis Rohingya: Dalam Perspektif ASEAN. Media Komunikasi FIS, 12(2).

Mangku, D. G. S., \& Itasari, E. R. (2015). Travel Warning in International Law Perspective. International Journal of Business, Economics and Law, 6(4).

Periani, A., \& Mangku, D. G. S. Implementation of Asean Convention On Counter Terrorism In Eradication Of Terrorism That Happens In The South Asia Area.

Purwanto, H., \& Mangku, D. G. (2016). Legal Instrument of the Republic of Indonesia on Border Management Using the Perspective of Archipelagic

State. International Journal of Business, Economics and Law, 11(4).

Purwendah, E., Mangku, D., \& Periani, A. (2019, May). Dispute Settlements of Oil Spills in the Sea Towards Sea Environment Pollution. In First International Conference on Progressive Civil Society (ICONPROCS 2019). Atlantis Press.

Mangku, D. G. S. (2018). Kepemilikan Wilayah Enclave Oecussi Berdasarkan Prinsip Uti Possidetis Juris. Jurnal Advokasi, 8(2), 150-164.
Mangku, D. G. S. (2017). The Efforts of Republica Democratica de Timor-Leste (Timor Leste) to be a member of Association of Southeast Asian Nations (ASEAN) and take an active role in maintaining and creating the stability of security in Southeast Asia. Southeast Asia Journal of Contemporary Business, Economics and Law, 13(4), 18-24.

Mangku, D. G. S., \& Radiasta, I. K. (2019). Tanggung Jawab Negara terhadap Penembakan Pesawat MH17 berdasarkan Hukum Internasional. Pandecta: Research Law Journal, 14(1), 25-33.

Yuliartini, N. P. R., \& Mangku, D. G. S. (2019). Tindakan Genosida terhadap Etnis Rohingya dalam Perspektif Hukum Pidana

Internasional. Majalah Ilmiah Cakrawala Hukum, 21(1), 41-49.

Widayanti, I. G. A. S., Mangku, D. G. S., SH, L. M., Yuliartini, N. P. R., \& SH, M. (2019). Penggunaan Tentara Anak Dalam Konflik Bersenjata Ditinjau Dari Perspektif Hukum Humaniter (Studi Kasus: Konflik Bersenjata Di Sri Lanka). Jurnal Komunitas Yustisia, 2(1).

Anggreni, I. A. K. N., Mangku, D. G. S., SH, L. M., Yuliartini, N. P. R., \& SH, M. (2019). Analisis Yuridis Pertanggungjawaban Pemimpin Negara Terkait 
Jurnal Media Komunikasi Pendidikan Pancasila dan Kewarganegaraan

Volume 2, Nomor 1 April 2020

Dengan Kejahatan Perang Dan Upaya Mengadili Oleh Mahkamah Pidana Internasional (Studi Kasus Omar Al-Bashir Presiden Sudan). Jurnal Komunitas Yustisia, 2(1).

Itasari, E. R., \& Mangku, D. G. S. Fulfillment Of Educational Rights For Indonesian Citizens Who Are In The Border Areas With Neighborhoods.

SETIAWATI, N., Mangku, D. G. S., SH, L. M., Yuliartini, N. P. R., \& SH, M. (2019). Penyelesaian Sengketa Kepulauan Dalam Perspektif Hukum Internasional (Studi Kasus Sengketa Perebutan Pulau Dokdo antara JepangKorea Selatan). Jurnal Komunitas Yustisia, 2(1).

Mangku, D. G. S., Triatmodjo, M., \& Purwanto, H. (2018). Pengelolaan Perbatasan Darat Antara Indonesia Dan Timor Leste Di Wilayah Enclave Oecussi (Doctoral dissertation, Universitas Gadjah Mada).

Purwanto, H., \& Mangku, D. G. S. Border Security In Indonesia And Papua New Guinea.

Mangku, D. G. S. Indonesian Government Authority In Terms of Border Management With Other Countries.

Mangku, D. G. S. (2018). Legal Implementation On Land Border Management Between Indonesia And Papua New Guinea According to Stephen B.
Jones Theory. Veteran Law Review, 1(1), 72-86. 